\title{
Serving the Nation: Devolution and the Civil Service in Wales
}

\begin{abstract}
Alistair Cole
The article captures the evolution of the moving object of Welsh devolution over its first decade through a case study of the civil service in Wales. Three positions are proposed as heuristics for understanding politico-administrative relations in devolved Wales: these are administrative persistence, capacity-building and bureaucratic capture. Rather than set these dynamics against each other, the case study of the civil service in Wales demonstrates the value of reasoning in terms of a mix of administrative, political and managerial pressures, requiring the development of hybrid responses and skills. Although the institutional capacity-building dynamic clearly had the ascendancy during the first decade, as the post-devolution Welsh polity gradually becomes more settled, there is likely to be a revival of more generic administrative andlor managerial concerns.
\end{abstract}

Keywords: Wales; devolution; civil service; bureaucracy

This article captures the evolution of the moving object of devolution over its first decade (more precisely from July 1999 to May 2010) through a case study of the civil service in Wales. Devolved government in Wales is investigated through the experience of the top civil service, both as a group and in terms of interactions with the new political class created by devolution. This area is largely under-explored (see also Parry 2001, 2004 and 2008; Prosser et al. 2006; Trench 2007). Why is this research endeavour interesting? There is a genuine puzzle revolving around how a previously constituted bureaucratic organisation and its actors adapt to a situation of rapid institutional change which might be interpreted as undermining a number of core 'civil service' values (Parry 2001). How civil servants react to a burgeoning and native political class in particular is a matter for empirical investigation of the type that can only be undertaken through sustained empirical research over the temporal long term (the first decade of devolution). Evidence is mainly presented in the form of semi-structured interviews carried out at three distinct periods throughout the decade: in 2001-02, midway through the first Assembly; in 2004, during the second Assembly; and in 2010, towards the end of the One Wales coalition of Labour and Plaid Cymru. ${ }^{1}$ Individual interviews provide important evidence about the conduct of politico-administrative relationships, fuller accounts than would be possible in any written documents. ${ }^{2}$ The method adopted is the most appropriate one for the task in hand; namely, to capture the experience over time of one particularly important yet neglected group at the heart of devolved government.

In an important work, Vernon Bogdanor (1999) evokes three dimensions of devolution: the transfer of power to an elected (but ultimately subordinate) assembly or parliament; the transfer of competencies on a geographical basis; and the transfer of competencies hitherto exercised by the Westminster parliament. In practice, devolution has produced three distinct 'sub-national' regimes, testament to historical 
contingencies and variable political identities and social demands in Scotland, Northern Ireland and Wales. England alone has no meaningful devolved institutions and retains in an exaggerated form the key features of a unitary state. Devolution has proceeded on the basis of the recognition of specific historical claims and ad hoc political and social demands, rather than embracing formal territorial principles that grant a constitutional status to sub-national governments.

\section{A Framework of Analysis}

The title of this article-Serving the Nation-begs the question, 'what sort of state is the contemporary United Kingdom?', the understanding of which is germane for appreciating the role of territorially based civil servants. The UK is clearly not a federal state, either of the co-operative or competitive variety, though it contains some quasi-federal elements within it. There is no detailed description of competencies in a written constitution, or a constitutionally guaranteed territorial order. Likewise, a description of the UK as a regional state of the Spanish variety would be highly misleading; there are, at present, no meaningful democratic regional institutions in England. The failure of the referendum in the north-east in 2004 laid to rest hopes of democratic English regions before the Conservative-led Coalition government abolished the regional development agencies altogether in 2010. Given the asymmetry of the UK post-devolution, however, it is clearly not a unitary state along the lines of the French one. Not only does experience of the state vary spatially, but there is no strong republican ideology upon which to base a principle of territorial uniformity, or overarching revolutionary moment to recalibrate centre-periphery relationships. The historic compromise between Scotland and England took the form of an Act of Union, and the fusion of two existing parliaments, rather than a pure absorption. After 1707 Scotland retained many distinctive features, including a separate education system, established church and a legal system based on Roman law. No such latitude was granted to Wales, whose Act of Union with England in 1536, and its subsequent interpretation, left much less room for identifying a distinct territorial basis for legislative or administrative action.

The UK has singularly lacked a continental European state tradition. It has failed to theorise the nature of its own state form or even to acknowledge the existence of a state, preferring to navigate the doctrines of crown privilege and parliamentary sovereignty (Dyson 2010). But, in practice, a British state model evolved which was highly London-centric, based on the unwritten and informal norms of the combined Westminster and Whitehall models. Adopting a longue durée perspective, Jim Bulpitt (1983) characterised the British elite's operation and way of thinking since the late 17th century in terms of a 'dual polity'. At the top, the elite was socialised into parliament ('Westminster') and into the civil service ('Whitehall'), and concerned itself with the core functions of the state (foreign policy, diplomacy, taxation). In its Whitehall guise, the model stressed anonymity, a culture of secrecy, a principle of 'behind closed doors' interactions and the support of formal doctrines of (political) accountability such as individual ministerial responsibility. The linked Whitehall and Westminster models justified politico-administrative interactions in a centralised microcosm with few links to provincial society. With the exception of the Thatcher period (1979-90), central responses to territorial pressures involved 
developing empirical solutions to deal with problems as they arose. In keeping with its ideology of the limited state, the formal apparatus of the centre was kept small. In the British 'dual polity' tradition, local government provided and administered services, a role shared with special purpose agencies and, in Wales, Scotland and Northern Ireland, with territorial departments in the form of the Scottish (18861999), Northern Ireland and Welsh (1964-99) Offices.

This brief survey is extremely important, in so far as maintaining the unified (i.e. British) home civil service was presented during the devolution debates in Scotland and Wales as one of the key safeguards for the future cohesion of the United Kingdom. The phrase senior civil service usually describes leading officials (grade 1 to 7) serving London-based functional ministries. But in Scotland and Wales, the development of increasingly powerful and decentralised territorial administrative offices from the late 19th century also created a cadre of civil servants located in Edinburgh and, later on, Cardiff. By 1997, the Welsh Office was responsible for 70 per cent of total public expenditure in Wales (Jones 2000). Much of the argument 2 put forward by pro-devolution campaigners concerned the desire to move away from the secretive world of the Welsh Office administration and towards more open and accountable government (Morgan and Mungham 2000; Laffin and Thomas 2001). As the leading civil servants of the day formed part of this 'secretive and unaccountable' system, it might be surmised that they would hold ambivalent views about devolution.

My case study of the civil service in Wales is informed by three theses that I label as administrative persistence, capacity-building and bureaucratic capture. Administrative persistence, my first thesis, draws theoretical sustenance from literatures in public management on the power of context and the weight of continuity (Argyis 1964; Ferlie 2004; Prosser et al. 2006). Observing the civil service over the decade of devolution might lend support to the persistence of existing administrative traditions. The traditional understanding of the British civil service is in terms of the 'Whitehall model', comprising the prominent traits of the political neutrality of civil servants, the tradition of the administrative 'generalist', lifelong career paths and the strong policy-advice role exercised by top officials (Pyper 1995; Page 2010). In the case of Wales, these traditional features of the Whitehall model were exercised in the Welsh Office (1964-99), a territorial rather than a functional department. The (politically driven) retention of the home civil service in the 1998 Devolution Acts in Wales and Scotland (considered below) might be interpreted as providing an overarching form of UK-level co-ordination based on retaining the core features of the British civil service.

My second position I describe as that of capacity-building (Cole 2006). Reduced to its core, capacity-building comprises two closely related but distinct components: political institutions and policy outputs. Formal institutional capacity refers most obviously to developing the rule-making potential of political institutions and their ability to define norms; informally, it also extends to developing (horizontal and vertical) relationships to maximise the effectiveness of policy outputs. This line of inquiry builds upon Hugh Heclo and Aaron Wildavsky's description of politicoadministrative interactions in terms of 'village life' (Heclo and Wildavsky 1974; Peters 2010). There is a common interest in making the institution legitimate; in 
Wales, this is embodied in new slogans such as 'Made in Wales', or the reference to specific features of small-country governance that are assumed to produce a convergence between politicians and administrators based on a mix of common values, or at least a common understanding of institutional goals. The second dimension of the debate on capacity is that of policy capacity, defined by Martin Painter and Jon Pierre $(2005,2)$ in terms of 'mobilising the necessary resources to be able to undertake the right collective choices and to fix strategic orientations for distributing scarce resources for public goods'. The emphasis on political leadership is one important dimension of this; another is the development of technical expertise within the Welsh Assembly Government (WAG).

My third thesis I label as that of bureaucratic capture, inspired in particular by the administrative state model of Joel Aberbach et al. (1981). Can we uncover evidence 3 of territorial civil servants capturing the governmental machine, or at least resisting attempts at political direction? Do civil servants use professional standards or managerial arguments to frame issues in terms of administrative inevitability, or to justify non-decision-making? (Aberbach and Rockman 2006) Do civil servants have a monopoly of expertise that they guard jealously, notably against politically nominated special advisers? Are existing administrative elites able to control any processes of management reform that they deem astute to implement? My focus to answer these questions is mainly on the executive branch known as the Welsh Assembly Government from around 2001 onwards, and identifiable with increasing clarity throughout the first decade of devolution.

These hypotheses, which are addressed in the next three sections, each generate new insights. They are not intended as 'equivalent' positions, however, in the form of logically competing alternatives that can be measured and presented in terms of a hierarchy of explanations. If they elucidate different dimensions of multi-level politico-administrative relationships, this is because the civil service in Wales itself stands at the crossroads of potentially conflicting tendencies that require the bridging of traditionally distinct objects of empirical analysis, namely politicoadministrative interactions, intergovernmental relations and trends in public management. The approach adopted facilitates the fine-grained appreciation of the contextual, temporal and spatial contingencies of politico-administrative relations in a new institutional context. At one level, the article is a precise, empirically grounded case study of the civil service in the specific spatial and political context of UK devolution. At a broader level of generality, however, it engages with generic dynamics of time and trust, institution-building, professional norms and multi-level dynamics.

\section{Recasting the Whitehall Model}

My first perspective is framed in terms of a traditional Weberian model of accountability, whereby in return for respect for their professional ethos, civil servants are expected to serve incumbent governments loyally. The core potential source of tension relates to which government. In the Scotland Act (1998) and the Government of Wales Act (1998), the civil servants working for the Welsh and Scottish devolved administrations remain as part of the home (British) civil service. In the 
1970s, there had reputedly been some civil service resistance to devolution-and Welsh civil servants had the same concerns in the run-up to devolution in 1999. Civil servants were worried about political influence in appointments, the extended use of special (politically appointed) advisers, and impediments to contacts with Whitehall. By 1997, however, the Scottish and Welsh Offices were the lead departments charged with drafting the devolution legislation, provided with back-up from the Cabinet Office (Parry 2001). The retention of the existing Civil Service Code provided a basis of stability and some instruments of leverage for officials on their new ministers. The decision to retain the home civil service was a political one; ministers considered that to move to separate devolved public services was unnecessary given all the other issues to be resolved in a short period of time. It probably also reflected the view of some civil servants that informal norms-the Whitehall way-would continue to ensure smooth co-operation between civil servants at the elite level. The decision to retain a unified home civil service was not inevitable. Northern Ireland has its own civil service and the principle of separate corps-such as the diplomatic service or the armed forces-is accepted in British public administration.

One decade later, there is little discussion or debate over the home civil service link. In the UK as a whole, the traditional model of neutrality, anonymity and secrecy had been weakened by outsourcing, flexibility and target-setting since the 1980s, long before devolution reached the statute books (Dowding 1995; Drewry 1995; Pyper 1995; Page 2010). All UK government departments have had the freedom since 1996 to set the pay, gradings and recruitment arrangements of their staff at the levels below the senior civil service. In terms of senior appointments, the Welsh and Scottish devolved administrations have both introduced principles of open competition which necessarily limit the involvement of the UK government (and the civil service commissioners). In the Welsh case, the 2004 Management Code requires that all senior grades are open to public tender and external advertising. The permanent secretaries of Scotland (2003) and Wales (2008) were appointed by panels wherein the prime minister's authority was delegated to the respective first ministers. ${ }^{3}$ In practice, the main gain from the unified home civil service is the ease of transfer into the devolved administrations; a number of grade 2 and 3 officials interviewed began their civil service career in other Whitehall departments. ${ }^{4}$

What, if anything, does the Whitehall model or the home civil service represent today? In interviews carried out in 2010 , the home civil service was valued among top officials in terms of values of political neutrality, public service and high ethical standards. Among generalists, the model of ethical propriety and independence was a core attraction of the home civil service which must not be jeopardised. Among the scientific and technical services (the economists, statisticians, scientists), the home civil service gave access to UK scientific networks that represented core benchmarks and repositories of professional expertise. These professional policy communities developed in importance over the decade as the WAG strengthened its own capacities. Hence, building devolved expertise depended on retaining access to the highest professional standards and the broader Whitehall policy community was important in this respect. Post-devolution officials had to work hard not to be excluded from these English-dominated networks. 
The second relevant dimension of discussion of the Whitehall model relates to intergovernmental relations within the broader British context. As this has been extensively investigated by Alan Trench (2005 and 2007), Richard Parry (2004), Rosanne Palmer (2008) and others, I will limit my investigation to interactions at the level of officials. Specifically writing on devolution, Parry $(2004,50)$ identifies two contrasting models of intergovernmental relations: 'diplomacy' and 'interdepartmental'. The interdepartmental style is the prevalent one in British politics. There is close connection between civil servants of Whitehall departments, sharing information and briefings. There is the expectation that policy advice will be given to ministers, and that the role of external policy advisers will be limited. The diplomatic style is akin to the interaction of sovereign powers whose powers are set out by protocols and procedures. The underlying assumption of devolution was that the interdepartmental style would normally prevail, but that diplomatic mechanisms would be put into place in case this did not work-or if nationalist parties arrived in office. In this spirit, a Memorandum of Understanding of 1998 set out the ground rules for interactions between the devolved administrations and the UK government. Concordats, devolution guidance notes and working-level agreements filled out many of the practical details (Trench 2007). Consistent with the principle of 'behind closed doors', informal mechanisms of intergovernmental relations have been favoured, symbolised by regular contacts between high-level civil servants promoted by the Cabinet Office and the head of the civil service, and the weekly meetings of the permanent secretaries, including those of the Welsh and Scottish administrations.

From the perspective of civil servants in Wales an evolution might be observed, from early tensions with Whitehall departments, through to the distancing of relationships at elite and middle-ranking levels and a gradual weakening of institutional memory and of Whitehall networks over time.

According to one well-placed interviewee: 'For the first two years of devolution, there were a lot of conflicts with Whitehall departments'. ${ }^{5}$ Consistent with the strong departmental traditions within the British civil service, relationships were to some extent dependent on the specific attitudes of central government ministries (which sometimes, but not always, were rooted in legal competencies). The response of Whitehall departments to devolution varied according to policy issuearea, stage of devolution and personal relationships. In the 2001-02 round, interviewees were generally critical of the lack of consistent principles steering relations between London and Cardiff. Some departments 'have been better than others' at understanding what devolution is about. The then Department of the Environment, Transport and the Regions (DETR) ${ }^{6}$ had sought to retain traditional powers of regulation of local government and attempted to impose the 'best value' policy irrespective of Welsh wishes. The Department of Agriculture and Rural Affairs (DEFRA) was the next worst culprit. Other departments had integrated devolution into their thinking. The Department of Education and the Department for Health had from the outset been more flexible, anticipating developments in Wales, as well as incorporating Welsh-inspired ideas into primary legislation. These accounts concur with those of other observers such as Trench (2005) for whom, in the case of Wales, the chief complaint is one of inconsistent treatment across government departments. 
The autonomy of Whitehall departments and the role of individual gatekeepers and veto players are central in these accounts. Although these very different relationships across Whitehall departments can in part be explained by personal relations ('and you can't legislate for personalities'), more important is how the devolved/ non-devolved split runs through a Whitehall department. In the case of Health, for example, some policy areas remained with central government-such as the regulation of the medical profession, or abortion—but everything else ( 90 per cent of all health areas) has been devolved. In this case, the relationship is mainly about benchmarking. The relationship was initially different with Education. Issues such as teachers' pay or student grants were not devolved in 2002, but the Assembly had a strong interest in these issues. By 2004, the devolution of higher education (including student fees) gave the WAG a greater input regarding the university sector. By 2004 also, DEFRA had lost influence through the reform of the Common Agricultural Policy (CAP) and the adoption by the WAG of a specific methodology for administering the CAP. Furthermore, the WAG had adopted a distinctive stance towards local government regulation and public services provision with the 'Making the Connections' agenda. ${ }^{7}$ Even in devolution-hostile sectors such as transport, there was a gradual increase in powers for the devolved authorities (Bradbury and Stafford 2010).

The nature of Cardiff-Whitehall contacts changed over the decade, in part as a result of harsh conflicts in relation to specific England and Wales acts or Legislative Competence Orders (LCOs). ${ }^{8}$ Greater expertise was accrued within the WAG to negotiate with Whitehall, notably through joining Bill Teams in Westminster or operating 'LCO units' within WAG departments. ${ }^{9}$ Political pressures could pull in conflicting directions. When not engaged in turf wars, among interviewees in 2001-04 the belief was widespread that the Whitehall machine did little actively to seek out the expertise of the civil servants based in the devolved territories, when, indeed, it did not simply ignore Wales, Scotland and Northern Ireland. In the words of one official with experience of Cardiff and London, 'there is great ignorance in Whitehall about Wales and devolution'. ${ }^{10}$ By the time of the 2010 round of interviews, civil servants declared themselves robust in terms of defending their prerogatives and in advocating Welsh interests in England and Wales bills. Especially after the passage of the 2006 Government of Wales Act, they felt better equipped to stand up to the devolution-sceptic Whitehall officials through insisting on their legal prerogatives. ${ }^{11}$

It lies beyond the scope of this article to engage in a fuller discussion of intergovernmental relations. If, for most of the first decade of devolution, intergovernmental relations involved a set of piecemeal arrangements, unwritten understandings and interpersonal contacts, by 2010 there had been an increasing resort to using 'diplomatic' instruments such as the Joint Ministerial Council (JMC), especially since the arrival in power of the Scottish National party (SNP) in Scotland in 2007. This development is likely to be reinforced by the Conservative-Liberal Democrat coalition's 'respect' agenda. Formal mechanisms of intergovernmental relations are likely to be more important in a context of divided party control and political asymmetry. In the broader UK context, the diplomatic model was given a boost by the agreement of a new Memorandum of Understanding, published in March 2010, with a disputes resolution procedure and a commitment between the governments 
to have a regular programme of meetings under the JMC umbrella (UK Parliament 2010). By the end of the decade the pendulum was shifting towards intergovernmental diplomacy.

\section{Village Life?}

My second thesis brought forth the metaphor of village life, a sense of common purpose and a blurring of the distinction between politics and administration. There is a common interest in making the institution legitimate; in Wales, this is embodied in narratives of joined-up governance and the dynamics of scale. The village life metaphor also relates to issues of transparency and accountability, and hence breaks quite sharply with some of the older conventions of public service such as secrecy and anonymity. The early interviews uncovered an unsettled civil service where civil servants were far busier than during the old Welsh Office, where they enjoyed much closer relationships with ministers in the post-devolution period than previously, when they were more involved in policy delivery and where they functioned in a 'goldfish bowl' of transparency and accountability (Cole et al. 2003). The civil service became much more focused on service delivery as a result of devolution, in part because the new ministers adopted a 'local government' rather than a 'central government' viewpoint, but especially because ministers were determined to make a difference. Almost one decade later, the novel features identified in the early round of interviews had become constants of politico-administrative interactions and were deeply ingrained in the policy-making style of Welsh devolution. The key shift over the period was from the National Assembly for Wales being a 'corporate body' to a clear separation of executive and legislative functions in the 2006 Government of Wales Act, a development with which top officials felt very comfortable.

In response to the question 'how has life changed under devolution?', all interviewees in 2001-02 complained of their increased workload. One official working in the Training and Education department reported a more widely diffused sentiment: 'We are much busier than before. We are dealing with one minister-Jane Davidson-whereas previously I dealt with Peter Hain, the secretary of state, who was involved with everything'. ${ }^{12}$ Officials had to prepare for and occasionally appear in front of committees, something for which most of them had no previous experience. One consequence of this increased activity was that there was 'a lot less thinking time', while ministers were constantly demanding higher levels of expertise and imposing a set of procedures (equality of opportunity, environmental sustainability and promotion of the Welsh language) that built extensive co-operation into the organisational mores of the Assembly. The sense of being overburdened was pervasive in the early interviews, as was the belief that adequate resources had not matched increased responsibilities. To quote one official:

During the Welsh Office days, we were staffed as an offshoot of Whitehall, relying on the lead department of Whitehall to do the bulk of the legwork. We tuned government policy to the Welsh perspective. We are now being asked to act as a free-standing government. ${ }^{13}$

This increased activity could be explained by the determination of ministers to make a difference. Whereas the secretary of state had been hands-off, with a very 
broad and general brief, the WAG was much more interventionist. In the past regime, ministers rarely engaged with civil servants. The briefs of ministers were inter-ministerial and communications tended to be by written documents, rather than face-to-face contact. As there were only three ministers-the secretary of state and two junior ministers-they were heavily reliant for their information on the Welsh Office civil servants. ${ }^{14}$ This dependency allowed civil servants to develop their ideas at a leisurely pace. Since 1999, there has been much closer contact with ministers. Informally, heads of department are in contact with ministers on a daily basis. For mid-ranking officials, contact ranges from supporting the minister in committee to organising internal meetings and assisting the minister in outside meetings. The nature of contacts between ministers and civil servants has changed in various ways. Ministers are now much more accessible. Moreover, civil servants now have more opportunity to be in contact with politicians of a different political hue, particularly during periods of coalition such as the One Wales government. Above all, there are now far more ministers, each ambitious in their own policy field. By the end of the first decade there was a cadre of very experienced ministers, who had 'developed a considerable expertise' in their subject area, who knew how to be a minister and who were unlikely to accept civil service advice uncritically. ${ }^{15}$ In terms of role reversal, one interlocutor contrasted the longevity in office of WAG ministers with cabinet experience with the high turnover of senior officials- the precise reverse of the stereotypical Whitehall model. ${ }^{16}$

Defining the devolutionary project in terms of joined-up public service delivery and against market solutions (believed to prevail in England) was a constitutive article of faith for many leading officials in Wales (Martin and Webb 2009). In the 2010 round of interviews, references to Team Wales, to the Beecham agenda, ${ }^{17}$ to co-operative modes of public service delivery, to policy innovation, to 'genuinely joining up' policy were diffused across the cadre of Welsh civil servants irrespective of their origins. ${ }^{18}$ At an elite level, at least, actors believed in a 'Wales effect'. In the opinion of one interlocutor: 'We've got better structures in Wales than in England. We've got Team Wales, we're small and we work closely together'. The reference to 'Team Wales', to signify the common sense of belonging to a territory with a strong identity, was believed to play in favour of developing closer relationships across organisations and encouraging personal contacts between the main organisational stakeholders. Much more than during the Welsh Office days, the civil servants interviewed believed they could perform a key role in orchestrating these horizontal contacts. The process of joining up was as important as the outcomes of being joined up. In the words of one interlocutor: 'collaboration is the name of the game, partnership's the name of the game, people understanding one another's agendas and working on a spatial basis is the name of the game' ${ }^{\prime}{ }^{19}$ These representations of reality are important in cognitive-normative terms, in so far as they are articulated by actors to make sense of their role and fuse personal, institutional and professional experiences.

In the follow-up interviews with Welsh civil servants in 2009-10, these core findings were confirmed as constants in the life of senior officials. The follow-up round of interviews revealed one apparent paradox that elucidates well the organisational ambition of the WAG. Although the belief in a Welsh public service was widely held, at the top end the senior civil service had become rather less recognisably Welsh than 
under the Welsh Office. Of the top officials interviewed in 2010, a number had been transferred from UK government departments-the Treasury, Education, Cabinet Office-from international associations such as Greenpeace or from bodies such as the NHS. As the WAG is fully in control of recruiting its top cadres, so it has sought to attract the best talent available through using head-hunting agencies and negotiating individual terms and conditions. This is less paradoxical than it seems at first sight. As the permanent secretary stressed, the WAG needs the best people for the jobwherever they come from. ${ }^{20}$

Civil servants are more than ever required to be generalists. Even those specialists who, upon recruitment, are dedicated to 'serving their science' become generalists in order to 'succeed and survive' ${ }^{21}$ As the WAG is a 'mini-Whitehall', so officials are required to demonstrate their multitasking abilities. The successful official needs, in the words of one civil servant, to be a 'jack of all trades', able to cover the ground of four-five colleagues in a standard Whitehall department. In spite of its growth, the WAG remains a modest-sized department to run all activities of a free-standing government. Moreover, officials need to master non-devolved areas as well, which spill over into their activity. On the other hand, professional specialists have gained in strength within the organisation. The first decade of devolution was marked by the development of the statistical and analytical services, of experts in political communications and marketing, along with the emergence of a far more sophisticated human resources policy. Strengthening the technical capacities of the WAG has produced ambitious specialists who are anxious to tie into tighter UK-wide professional networks of economists, statisticians, scientists and medical officials, and who look to the broader UK context for professional accreditation and reputation. In this respect, as in others, the 2010 round of interviews also revealed a senior civil service that was beginning to develop a harder managerial edge.

\section{Bureaucratic Capture?}

In the specific area of politico-administrative relations, three core developments would appear to run counter to any interpretation based on bureaucratic capture; these concern the strengthening of the first minister's office, the role of special advisers, and attempts by the political executive to intervene in the broad debate about who is a public servant.

The most significant development has been the emergence of a recognisable Welsh political and partisan leadership, symbolised for most of the period by the figure of Labour First Minister Rhodri Morgan and the rhetoric of 'clear red water'. Over the decade, we observe a strengthening of bureaucratic and advisory resources at the disposal of the political leadership in general and the first minister in particular. As in Scotland, the first minister has developed his own powerful group of advisers-in part civil servants, in part political appointees-with particular expertise in the area of European Union policy (Lynch 2006; Palmer 2008). The longevity of First Minister Morgan's tenure (almost 10 years) had as a by-product the soaking up of new responsibilities within what has become the Department of First Minister in Cabinet. Under First Minister Carwyn Jones, the Department of First Minister in Cabinet was described by insiders as part of the 'strategic centre', with 
responsibilities for the office of the first minister, the Cabinet Secretariat (which plans and co-ordinates the cabinet's work programme), the ministerial support division, constitutional affairs and public administration, Europe and external affairs, communications and knowledge and analytical services. ${ }^{22}$

The second core development has been the introduction of special advisers (commonly known as SPADs). Relations between officials and special advisers are 'very, very, very, very frequent'. ${ }^{23}$ In the 2001-02 interviews there was some suspicion of these part-political, part-expert temporary appointees, consistent with a traditional conception of the Whitehall model. By 2010, all officials interviewed converged in their belief that there were good relations with the special advisers. Two categories of SPADs were identified in interviews; the 'party hacks' and the 'policy experts'. The former were valued by officials because they helped them anticipate the likely political reaction to any proposals they might make. The SPADs fully came into their own during periods of coalition government, where it was not uncommon for one official to be responsible to ministers from two different parties (Plaid Cymru and Labour). Some civil servants claimed not to have the political expertise to know what the minister wants: 'we can test ideas out with special advisers, before actually putting them formally to Ministers' ${ }^{24}$ Officials were more divided in relation to policy expertise: 'we have a few people dotted around the Ministers, but they're not that high calibre, to be honest' ${ }^{25}$ In addition to the SPADs, civil servants referred to the diversification of sources of policy advice to ministers, from a variety of think tanks, and from party.

Third, the political executive has intervened in the debate about who is a public servant. As first minister, Rhodri Morgan supported the concept of 'the Welsh public service', as a pool of talent bridging the civil service, the NHS, local government and other forms of public service. Under the Public Sector Management Wales programme (2004) the WAG declared itself committed to encouraging secondments between public sector organisations across Wales, as well as supporting common training for officials across the public sector. In interviews, however, I found limited support among top officials for the concept of a broader Welsh public service distinct from, or as an alternative to, the existing civil service-and officials remained suspicious of local government in particular. Far more significant was the decision taken to bring 'in house' the main Assembly-sponsored public bodies: the Welsh Development Agency (WDA), the Wales Tourist Board (WTB) and Education and Learning Wales (ELWa), operational since 2006. Abolishing the 'quangos' had the advantage, from the perspective of officials, of bringing in house previously more autonomous functions and of strengthening the personnel deficit that had been identified in the early years of devolution.

Civil service actors have contributed in key ways to developing the capacity of devolved government in Wales. The permanent secretary is key to the organisation chart. The permanent secretary, the only grade 1 official in Wales, is chief accounting officer, ${ }^{26}$ with formal responsibility for the budgetary, legal and political propriety of all acts of the WAG. This position requires the undertaking of a number of formal roles that would be recognisable in any bureaucratic organisation. One is that of arbitration: the permanent secretary determines where any particular dossier should be treated within the administration. A second role involves protecting the civil 
service staff from undue pressure, from the first minister or his cabinet colleagues, or an Assembly Committee. ${ }^{27}$ The key dialogue occurs between the permanent secretary, who represents the permanent administration, and the first minister, at the head of cabinet. A third role is as guarantor of the neutrality of the machinery of state; in the event of disagreement with a minister, the permanent secretary can insist on receiving a written 'ministerial directive'. ${ }^{28}$ The role of permanent secretary is also shaped by personal preferences and leadership style. The first permanent secretary, Rachel Lomax (1996-99), left at the very beginning of our period of investigation (see Prosser et al. 2006, for detailed analysis). For most of the period of embedding devolution (1999-2008), the second permanent secretary, Sir Jon Shortridge, saw his role as one of ensuring a smooth transition to the new devolution arrangements, of defining rules and codes of behaviour to ensure that the ethical standards of a traditional civil service model were upheld in the new regime. ${ }^{29}$ Associates of the incumbent permanent secretary, Gillian Morgan, evoke a 'charismatic form of leadership', an 'outward-facing' sense of entrepreneurship which contrasted with the more cautious style practised by her predecessor. Morgan has assumed a more prominent public role, not least by criticising the lack of understanding of Welsh issues in Whitehall (Morgan 2009).

The styles adopted by the successive permanent secretaries have responded both to the nature of the challenges of the institution at a given time and to personal qualities and leadership preferences. The Shortridge period was associated with the embedding of devolution and development of powerful ministerial portfolios. While the permanent secretary had been the key actor during the Welsh Office, the main interlocutor of the secretary of state, the decade of devolution strengthened individual ministerial portfolios and, as a consequence, created powerful relations between ministers and 'their' directors, to some extent at the expense of the co-ordinating role of the permanent secretary. Such a shift in bureaucratic power was formalised in 2003, when Shortridge established the sub-accounting officers, a formal recognition that much bureaucratic power had moved to the individual heads of department and that there were now multiple points of political authority. ${ }^{30}$ Without challenging the sub-accounting officer decision, Permanent Secretary Morgan attempted to use her control over the organisation chart to provide more 'joined-up' forms of steering. She identified her main achievement thus far as the creation of a new category of director generals, seven super-managers whose role is to overcome the 'silo mentality' of individual departments and to promote 'joined-up' solutions. ${ }^{31}$ While the 30 or so director and deputy-director posts are focused on operational delivery, the director general position was imagined as an attempt to build strategic-level capacity.

Closely associated to this innovation was the creation of a streamlined Strategy and Performance Board ${ }^{32}$ and a slightly larger Business Group, ${ }^{33}$ replacing the former Management Board, described by one participant as 'like the United Nations with too many people' ${ }^{34}$ These efforts at bureaucratic co-ordination and oversight have run against the pressure from knowledgeable and politically ambitious ministers to have access to 'their' director, hence cutting out the theoretical overlords. In a quote reminiscent of William Niskanen's (1971) budget maximising, one official observed that 'there are very, very strong forces within government to appoint a Minister, a Department underneath them, and to judge both by the size of the empire' ${ }^{35}$ 
Ministers are not only ambitious, but seek to cultivate one-to-one relationships with 'their' officials, in most cases the directors or deputy directors, who in practice organise their senior management teams to deal with the main areas of delivery. Such compartmentalisation is reinforced by budgetary rules, with a strict division along discrete budgetary lines and a very limited capacity for directors or director generals to vire across budgets. ${ }^{36}$ Pooled budgets would allow for more joined-up thinking, but as it stands, in the words of one director general, 'the money is locked up in separate pots that are negotiated at a political level and I don't have flexibility between those pots'.$^{37}$ These sectoral pressures, producing a tight ministerdepartmental nexus, run against the early Assembly design that actively challenged the legitimacy of such relationships in the interests of 'joined-up' government.

The above evidence casts doubt on any bureaucratic capture thesis in the case of devolution in Wales. Throughout the decade, the core drivers of devolution were (party) political. As one interlocutor argued:

If you look at the headline political strategy documents that this place has produced over the last 10 years, 'Wales, a Better Country' in 2003 emphasised the top 10 manifesto commitments, rather than any other particular targets in any numerical sense, and, of course, the coalition formed in 2007 stressed the One Wales coalition agreement commitments rather than any particular comprehensive set of KPIs. ${ }^{38}$

For as long as Rhodri Morgan remained first minister, respecting party or coalition engagements was accompanied by a distrust towards defining key performance indicators as understood in the broader UK context and as symbolised by the refusal to collect data on school performances across Wales. ${ }^{39}$

Towards the end of the first decade of devolution, insiders noticed a shift, particularly after the departure of Morgan. The onset of the financial crisis concentrated minds. A new harder edge made itself felt, typified by public expenditure cuts, new strategies of public management in education, mooted reforms of local government and deeply uncertain budgetary prospects in the future. One response to these new circumstances was a new emphasis on delivery and a more robust reference to performance management and key performance indicators, typified by the 'management for delivery' dashboard system championed by Permanent Secretary Morgan. ${ }^{40}$ There was a push after the change of first minister in 2009 to introduce harder inspection methods and to make more performance data available in health, education and social services. If the discourse of 'clear red water' had skewed discussions of performance for fear of comparisons with England, the onset of financial austerity brought the public service performance of the WAG into the public limelight and emboldened those politicians and civil servants for whom the next stage of devolution (the full law-making powers granted by referendum in March 2011) would require a more explicit focus on performance.

\section{Conclusion}

In my framework of analysis, three theses were proposed for understanding politicoadministrative relations in devolved Wales: these were administrative persistence, 
capacity-building and bureaucratic capture. Taking the period as a whole, the thesis of bureaucratic capture appears the least robust in the case of post-devolution Wales. The key organisational choices (such as the decisions to absorb agencies into the governmental machinery, and to resist the Private Finance Initiative) were political ones, originally taken without much regard for civil service views and dictated by the political imperative to demarcate Cardiff from London. By the end of the period, however, as the WAG became more of a 'normal' government, so the early heroic style began to give way to a tougher performance management regime, a trend that can only be strengthened in the context of fiscal penury.

Moving to the administrative persistence thesis, in some respects the Whitehall model has demonstrated remarkable persistence and has not been undermined by politicisation or by preferential treatment for Welsh speakers, both of which were pressing concerns of many civil servants and others prior to devolution. Civil servants have demonstrated their ability to work with politicians of different persuasions and advise all parties prior to Assembly elections; the tradition of their (party) political neutrality is fully respected. Can we identify a generation effect, whereby older officials cherish their civil service identity, while younger officials are more explicitly mobilised by the prospect of serving their nation? Interviews revealed considerable support for retaining close links with Whitehall—and not only from representatives of the older Welsh Office generation. The need for continuing linkage with Whitehall could in part be related to the developing institutional capacity of the WAG itself. The specialist and technical services benchmark themselves against the best professional practice in Whitehall. Moreover, the Whitehall link continues to allow the infusion of the best talent from across the UK (a remark that extends to the Scottish case). If anything, officials complained of being left out of the loop by Whitehall departments.

So, what is specific about Wales? Does it relate to career origins? Our survey revealed a rather diverse set of career origins among top civil servants in the WAG. On the basis of the 2010 sample there is no real evidence of 'clubness', in the sense of recruiting a self-referencing administrative elite. ${ }^{41}$ The chief self-assessed distinctiveness, among my interview panel, concerned the type of civil servant who wanted to work in Wales; civil servants were expected to be sympathetic with the cause of devolved government, rather than avowedly neutral.

A second distinctive feature relates to the nature of politico-administrative relationships themselves. Devolution in Wales-in particular and more so than in Scotland-is associated with an accountability and transparency agenda. Leading civil servants such as Permanent Secretary Morgan are public figures, not afraid to publicise their views on intergovernmental relationships in the media. The transparency of Welsh devolution is part of the core justification for devolution itself, embodied by a commitment to more open government, the publication of cabinet minutes, of the composition of cabinet committees and the wide range of formal documents placed on the Assembly Government's website. The metaphor of village life helps to capture both the intensity and the transparency of interactions; the 'goldfish bowl' breaks with key aspects of secrecy, anonymity and confidentiality that long characterised the Whitehall model.

One response to the question, 'how far are WAG civil servants diverging from their UK counterparts?' is that they function within a very distinctive environment, a 
'mini-Whitehall' serving a devolved government with an ambitious political project which is defined in part against the perceived neo-liberal model prevalent in England. Recent work on public services reform in England and Wales shows clear evidence of this constructed policy divergence, as England has introduced hardedged, top-down performance regimes based on 'terror and targets' which policymakers in Wales have eschewed in favour of 'partnership' between central and local government (Martin and Webb 2009). Were officials discouraged from drawing positive policy lessons from English experience under the broad steer to develop 'Made in Wales' policies? The evidence from our interviews is inconclusive. More specifically focusing on the civil service, there are several signs of distancing with Whitehall such as the role of special advisers at every level of the WAG, or the falling into disuse of the convention of seconding new recruits into Whitehall departments. Most important, however, is the diminishing contact with Whitehall departments as the logic of devolved government produces more distinctive policy outputs and less perceived need to develop networks at the UK level.

Political capacity is my preferred conceptualisation for describing the development of devolution in Wales. Capacity-building most obviously refers to developing the rule-making potential of political institutions. One interpretation of devolution in Wales is as a decade-long constitutional convention, with the evidence base provided in the form of reports produced from outside the formal bureaucracywhether the National Assembly Advisory Group, the Richard Commission or the Parry Jones Convention. Such institutive politics (Stirbu 2009) is only one part of the edifice, but has provided the context within which the civil service functions. Civil servants are part of a broader enterprise of building capacity for the devolved institutions. They have a self-perception as a servant of the Welsh Assembly Government rather than a more generic professional identity as a group or a corps in public administration. The second dimension of the debate on capacity is that of policy capacity. Our survey demonstrates quite clearly the weight of expectations upon civil servants to produce innovative and original policies, to serve a 'freestanding government'. They have been helped by the growth in numbers; by the integration of expertise from agencies; and by the development of new professional and scientific services. The key analytical point is that civil service resources have developed as part of a more general process of building institutional capacity over the first decade of devolution. As the WAG has developed its legal competencies, so it has needed to strengthen its policy expertise; special advisers, think tanks, professional groups and party notwithstanding, the civil service remains central in the provision of policy advice.

My case study raises more general issues of co-ordination that are common across democratic bureaucratic systems, all faced with potentially conflicting pressures of maintaining professional standards, demonstrating commitment to the political leadership and promoting best practice in management change (Peters 2010). The specific mix varies according to place. Attempts to ensure political steering often involve some measure of politicisation of top civil service appointments (the US spoils system), the development of parallel bureaucratic structures (French-style cabinets), the hiving off of policy delivery to specialised agencies or, on the contrary, the creation of mega-ministries (Pyper 1995). In the case of Wales, the transformations of the first devolutionary decade were consistent with the broader context 
of the British state tradition, namely an absence of a defining constitutional moment, an incremental process of adaptation and a set of partly informal understandings. But this tradition is being gradually reshaped by moves towards a formal diplomatic mode of intergovernmental relations, and by the development of much clearer formal and informal institutions upon which to base devolved Welsh and Scottish governments. The civil service has played an unsung yet important role in accompanying this ongoing evolution of the British constitution.

\author{
About the Author \\ Alistair Cole, Professor of Politics, School of European Studies, 65-68 Park Place, Cardiff, Wales, \\ CF10 4NP, UK, email: ColeA@Cardiff.ac.uk
}

\title{
Notes
}

1. The 2001-04 interviews were carried out with a panel of politico-administrative actors that incorporated, inter alia, the Wales Office, the first and deputy first minister, the Policy Unit, the Cabinet and Constitution Unit, the education and deputy education ministers, officials in the Training and Education division (x 4), the European and External Affairs division (x 2), the WDA (x 3), ELWa (x 3), WTB (x 2), the Presiding Office (x 2) and the Committee Secretariat (1). Interviews were conducted at director, deputy director and special adviser levels, as well as with a broad range of politicians (ministers and Assembly members) and in the broader policy community. Anonymised transcripts for most interviews are contained in 'Devolution and decentralisation in Wales and Brittany, 2001-2002', UK Data Archive (http://www.dataarchive.ac.uk), Study Number 4802. From January to June 2010, 12 interviews were carried out 4 with senior civil servants of the WAG, at permanent secretary, director general, director and deputy director levels. These interviews were organised, conducted and transcribed as part of the activities of the ESRC- and HEFCW-funded Wales Institute for Research, Data and Methods (WISERD) and Cardiff University's Wales Governance Centre.

2. A semi-structured interview schedule was used both in 2001-04 and 2010, combining a number of identical questions with more period-specific ones in each case. Questions concerned the role of the senior civil service in Wales; relations with ministers; the home civil service and the Whitehall model; the Welsh public service; the management of the civil service under devolution; recruitment pathways; generalists and specialists; the modernisation agenda; attitudes to think tanks; special advisers; political parties; relations between the Park and the Bay; and the interests of the devolved government in EU policy.

3. In the case of Scotland, rather paradoxically, the new Scottish Government permanent secretary appointed in 2010 was transferred from Whitehall without advertisement, thus demonstrating the practical utility of the home civil service link, as well as the right of the Scottish Government to determine how it selects its leading officials.

4. In the words of one interviewee (WAG, March 2010): 'we get some good people, what we don't do on the whole is get people going from here to London'.

5. Interview, National Assembly for Wales, 2002.

6. Departments are given the titles they possessed at the moment interviews were carried out.

7. 'We're all broadly signed up to that, and even the political parties, I suspect, are really signed up to, to all of that'. Interview, WAG, April 2010.

8. The Legislative Competence Order refers to the complex procedure introduced in the 2006 Government of Wales Act, whereby the National Assembly for Wales can draw down legislative powers with agreement of the UK parliament. The move to full legislative powers in the March 2011 referendum renders such a procedure superfluous. 


\author{
9. Interview, WAG, February 2010. \\ 10. Interview, WAG, February 2010.
}

11. This theme emerged in several interviews in February-June 2010.

12. Interview, NAfW, 2002.

13. Interview, NAfW, 2002.

14. Interviews, NAfW, 2002 and WAG, 2010.

15. Interviews, WAG, 2010.

16. Interview, WAG, 2010.

17. The Beecham report called for partnership modes of public service delivery, including collaboration with the non-devolved agencies such as the Police and Job Centre Wales.

18. The 2010 interview sample included an even distribution between former officials of the Welsh Office, those who had risen to the top under devolution and those who had come in from the outside.

19. Interview, WAG, April 2010.

20. Interview, June 2010.

21. Interview, WAG, March 2010.

22. Interview, WAG, March 2010.

23. Interview, WAG, March 2010.

24. Interview, WAG, April 2010.

25. Interview, WAG, March 2010.

26. 'The point of being an accounting officer or sub-accounting officer is that you're personally responsible for the propriety, and the regularity of the way in which public money is being spent. And so, you are in the dock personally, if things break the rules'. Interview, WAG, February 2010.

27. Interview, WAG, June 2010.

28. A possibility regarded in an interview with the permanent secretary as the 'nuclear option' and very unlikely to materialise. It is worth pointing out that this mechanism is a direct carry-over from the pre-devolution period and a more general instrument of bureaucratic influence.

29. This account is based on the converging testimony of several civil servants who worked closely with Jon Shortridge.

30. When asked about the sub-accounting officer role, one civil servant explained: if there is an issue, then I'll go and discuss it with the minister, and, to date, they've always taken, taken my advice'. Interview, WAG, March 2010.

31. Interview with Gillian Morgan, June 2010.

32. The Strategy and Performance Board meets weekly. It brings together the permanent secretary and the director generals, or DG equivalents.

33. The Business Group is a larger meeting than the Strategy and Performance Board. It meets once a month on average.

34. Interview, WAG, February 2010.

35. Interview, WAG, February 2010.

36. '... so I can't make a decision, for example, that we should vire money from $\bullet \bullet$ to $\bullet \bullet$, though both are under my theoretical control'. 
JOBNAME: No Job Name PAGE: 18 SESS: 7 OUTPUT: Fri Aug 12 17:54:17 2011 SUM: 00285B07

/v2501/blackwell/B_journals/BJPI_v0_i0/bjpi_470

37. Interview, WAG, March 2010.

38. Interview, WAG, February 2010.

39. Interview, WAG, February 2010.

40. This is an IT-based system covering all departments, with a top-level set of strategic outcomes and with indicators identified at all levels of the organisation.

41. Our sample concerned only the very senior civil service.

\section{Bibliography}

Aberbach, J. D., Putnam, R. and Rockman, B. D. (1981) Bureaucrats and Politicians in Western Democracies (Cambridge MA: Harvard University Press).

Aberbach, J. D. and Rockman, B. A. (2006) 'The past and the future of political-administrative relations: Research from bureaucrats and politicians into the web of politics and beyond', International Journal of Public Administration, 29:12.

Argyis, C. (1964) Integrating the Individual and the Organisation (New Haven CT: Yale University Press).

Bogdanor, V. (1999) Devolution in the United Kingdom (Oxford: Oxford University Press).

Bradbury, J. and Stafford, I. (2010) 'The effectiveness of legislative mechanisms for the devolution of powers in the UK: The case of transport devolution to Wales', Public Money and Management, 30:2, 97-102.

Bulpitt, J. (1983) Territory and Power in the United Kingdom (Manchester: Manchester University Press).

Cole, A. (2006) Beyond Devolution and Decentralisation: Building Regional Capacity in Wales and Brittany (Manchester: Manchester University Press).

Cole, A., Jones, J. B. and Storer, A. (2003) 'Inside the National Assembly for Wales', Political Quarterly, $74: 2,223-232$.

Deacon, R. (2002) The Governance of Wales: The Welsh Office and the Policy Process, 1964-99 (Cardiff: Welsh 7 Academic Press).

Dowding, K. (1995) The Civil Service (London: Routledge).

Drewry, G. (1995) 'The civil service: From the 1940s to "next steps" and beyond', Parliamentary Affairs, $48: 4,583-595$.

Dyson, K. (2010) The State Tradition in Western Europe (London: ECPR Press).

Ferlie, E. (2004) 'On building the new managerialist state', British Journal of Management, 14, 585-596. 8

Heclo, H. and Wildavsky, A. (1974) The Private Government of Public Money: Community and Policy inside British Politics (London: Macmillan).

Jeffery, C. (2000) 'Sub-national mobilisation and European integration: Does it make a difference?', 9 Journal of Common Market Studies, 38:1, 1-23.

Jones, J. B. (1990) 'The Welsh Office: A political expedient or an administrative innovation?', The 10 Transactions of the Royal Society of Cymmrodorion, Cardiff, pp. 281-292.

Keating, M. and Cairney, P. (2006) 'A new elite? Politicians and civil servants in Scotland after devolu- 11 tion', Parliamentary Affairs, 59:1, 43-59.

Laffin, M. and Thomas, A. (2001) 'New ways of working: Political-official relations in the National Assembly for Wales', Public Money and Management, 21:2, 45-51.

Lynch, P. (2006) 'Governing devolution: Understanding the office of first ministers in Scotland and Wales', Parliamentary Affairs, 59:3, 420-436.

Martin, S. J. and Webb, A. G. (2009) 'Citizen-centred public services: Contestability without consumerism', Public Money and Management, 29:2, 123-130.

Morgan, G. (2009) 'Gear change for our civil service', Agenda, Autumn, 6-9.

Morgan, K. and Mungham, G. (2000) Redesigning Democracy: The Making of the National Assembly for Wales (Bridgend: Poetry Wales Press).

Niskanen, W. (1971) Bureaucracy and Representative Government (Chicago IL: Aldine-Atherton). 
JOBNAME: No Job Name PAGE: 19 SESS: 7 OUTPUT: Fri Aug 12 17:54:17 2011 SUM: 9A3E5015

/v2501/blackwell/B_journals/BJPI_v0_i0/bjpi_470

Page, E. C. (2010) 'Has the Whitehall model survived?', International Review of Administrative Sciences, 76:3, $407-423$.

Painter, M. and Pierre, J. (2005) 'Unpacking policy capacity: Issues and themes', in M. Painter and J. Pierre (eds), Challenges to State Policy Capacity: Global Trends and Comparative Perspectives (Basingstoke: 12 Palgrave Macmillan), 2.

Palmer, R. (2008) Devolution, Asymmetry and Europe: Multi-level Governance in the United Kingdom (Brussels: Peter Lang).

Parry, R. (2001) 'Devolution, integration and modernisation in the United Kingdom civil service', Public Policy and Administration, 16:3, 53-67.

Parry, R. (2004) 'The civil service and intergovernmental relations', Public Policy and Administration, 19:2, 50-65.

Parry, R. (2008) 'Changing UK governance under devolution', Public Policy and Administration, 23:4, 114-120.

Peters, B. G. (2010) The Politics of Bureaucracy (London: Routledge).

Prosser, S., Connolly, M., Hough, R. and Potter, K. (2006) Making it Happen in Public Service: Devolution in Wales as a Case Study (Exeter: Imprint Academic).

Pyper, R. (1995) The British Civil Service (Hemel Hempstead: Harvester Wheatsheaf).

Rawlings, R. (2003) Delineating Wales (Cardiff: University of Wales Press).

Stirbu, D. S. (2009) 'Instituting constitutions: Welsh constitutional dynamics and the development of the National Assembly for Wales 2005-2007', Contemporary Wales, 22:1, 95-112.

Trench, A. (2005) The Dynamics of Devolution: The State of the Nations 2005 (Exeter: Imprint Academic).

Trench, A. (2007) 'Washing dirty linen in private: The processes of intergovernmental relations and the resolution of disputes', in A. Trench (ed.), Devolution and Power in the United Kingdom (Manchester: Manchester University Press), 160-197.

UK Parliament. (2010) 'Memorandum of Understanding and Supplementary Agreements between the United Kingdom Government, the Scottish Ministers, the Welsh Ministers and the Northern Ireland Executive Committee', 57. 


\begin{tabular}{|l|l|}
\hline \multicolumn{2}{|c|}{ Toppan Best-set Premedia Limited } \\
\hline Journal Code: BJPI & Proofreader: Elsie \\
\hline Article No: 470 & Delivery date: 12 August 2011 \\
\hline Page Extent: 19 & \\
\hline
\end{tabular}

\section{AUTHOR QUERY FORM}

Dear Author,

During the preparation of your manuscript for publication, the questions listed below have arisen. Please attend to these matters and return this form with your proof.

Many thanks for your assistance.

\begin{tabular}{|c|c|c|}
\hline $\begin{array}{c}\text { Query } \\
\text { References }\end{array}$ & Query & Remark \\
\hline q1 & $\begin{array}{l}\text { AUTHOR: Prosser } 2006 \text { has been changed to } \\
\text { Prosser et al. } 2006 \text { so that this citation } \\
\text { matches the Reference List, please confirm } \\
\text { that this is correct. }\end{array}$ & \\
\hline $\mathrm{q} 2$ & $\begin{array}{l}\text { AUTHOR: Jones } 2000 \text { has not been included } \\
\text { in the Bibliography. Please provide a full } \\
\text { reference. }\end{array}$ & \\
\hline $\mathrm{q} 3$ & $\begin{array}{l}\text { AUTHOR: Aberbach (1981) has been } \\
\text { changed to Aberbach et al. (1981) so that this } \\
\text { citation matches the Reference List, please } \\
\text { confirm that this is correct. }\end{array}$ & \\
\hline $\mathrm{q} 4$ & $\begin{array}{l}\text { AUTHOR: Please check this website address } \\
\text { and confirm that it is correct. (Please note that } \\
\text { it is the responsibility of the author(s) to } \\
\text { ensure that all URLs given in this article are } \\
\text { correct and useable.) }\end{array}$ & \\
\hline q5 & $\begin{array}{l}\text { AUTHOR: Please provide interview details } \\
\text { for Note } 36 .\end{array}$ & \\
\hline q6 & $\begin{array}{l}\text { AUTHOR: Please provide the page range for } \\
\text { Aberbach \& Rockman } 2006 .\end{array}$ & \\
\hline q7 & $\begin{array}{l}\text { AUTHOR: Deacon, } 2002 \text { has not been cited } \\
\text { in the text. Please indicate where it should be } \\
\text { cited; or delete from the Reference List. }\end{array}$ & \\
\hline q8 & $\begin{array}{l}\text { AUTHOR: Please provide the issue no. for } \\
\text { Ferlie 2004. }\end{array}$ & \\
\hline q9 & $\begin{array}{l}\text { AUTHOR: Jeffery, } 2000 \text { has not been cited in } \\
\text { the text. Please indicate where it should be } \\
\text { cited; or delete from the Reference List. }\end{array}$ & \\
\hline
\end{tabular}




\begin{tabular}{|c|c|}
\hline $\mathrm{q} 10$ & $\begin{array}{l}\text { AUTHOR: Jones } 1990 \text { has not been cited in } \\
\text { the text. Please indicate where it should be } \\
\text { cited or advise if it can be deleted. }\end{array}$ \\
\hline q11 & $\begin{array}{l}\text { AUTHOR: Keating, Cairney, } 2006 \text { has not } \\
\text { been cited in the text. Please indicate where it } \\
\text { should be cited; or delete from the Reference } \\
\text { List. }\end{array}$ \\
\hline $\mathrm{q} 12$ & $\begin{array}{l}\text { AUTHOR: Please check the page range for } \\
\text { Painter \& Pierre } 2005 .\end{array}$ \\
\hline $\mathrm{q} 13$ & $\begin{array}{l}\text { AUTHOR: Rawlings, } 2003 \text { has not been cited } \\
\text { in the text. Please indicate where it should be } \\
\text { cited; or delete from the Reference List. }\end{array}$ \\
\hline q14 & $\begin{array}{l}\text { AUTHOR: Please provide name and location } \\
\text { of publisher for UK Parliament } 2010 .\end{array}$ \\
\hline
\end{tabular}


Required software to e-Annotate PDFs: Adobe Acrobat Professional or Adobe Reader (version 8.0 or above). (Note that this document uses screenshots from Adobe Reader $\mathrm{X}$ )

The latest version of Acrobat Reader can be downloaded for free at: http://get.adobe.com/reader/

Once you have Acrobat Reader open on your computer, click on the Comment tab at the right of the toolbar:

닙

This will open up a panel down the right side of the document. The majority of tools you will use for annotating your proof will be in the Annotations section, pictured opposite. We've picked out some of these tools below:

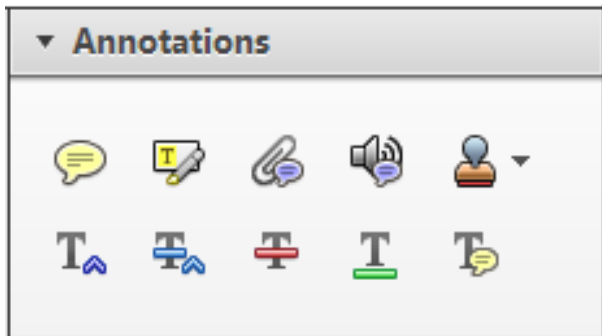

1. Replace (Ins) Tool - for replacing text.

Strikes a line through text and opens up a text box where replacement text can be entered.

\section{How to use it}

- Highlight a word or sentence.

- Click on the Replace (Ins) icon in the Annotations section.

- Type the replacement text into the blue box that appears.

Idard tramework for the analysis of $\mathrm{m}$ icy-Nevertheless, it also led to exog،

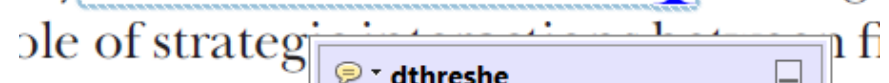
aber of comp 08/06/2011 15:58:17

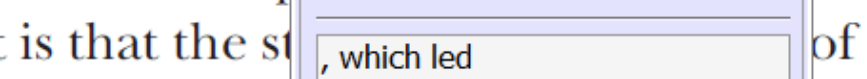
nain compo: be level, are exc nc

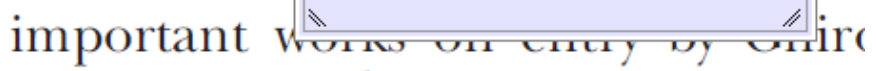
M heneferth) ${ }^{1}$ we anen the 'hlark $\mathrm{h}$

3. Add note to text Tool - for highlighting a section to be changed to bold or italic.

T Highlights text in yellow and opens up a text box where comments can be entered.

\section{How to use it}

- Highlight the relevant section of text.

- Click on the Add note to text icon in the Annotations section.

- Type instruction on what should be changed regarding the text into the yellow box that annears.

namic responses of mark ups ent with the VAR evidence

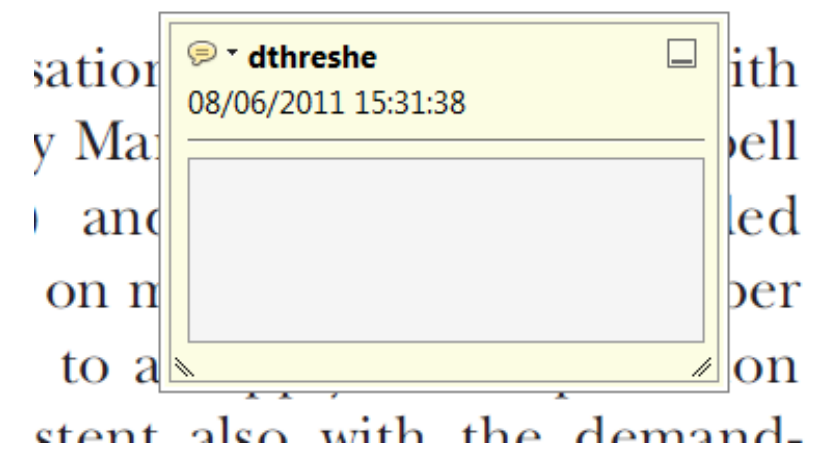

2. Strikethrough (Del) Tool - for deleting text.

Thikes a red line through text that is to be deleted.

\section{How to use it}

- Highlight a word or sentence.

- Click on the Strikethrough (Del) icon in the Annotations section.

there is no room tor extra prohts al c ups are zero and the number of ret) values are not determined by Blanchard and Kiyotaki (1987), rfect competition in general equilil ts of aggregate demand and supply lassical framework assuming monol eon an evorenois number of firms

\section{Add sticky note Tool - for making notes at} specific points in the text.

Marks a point in the proof where a comment needs to be highlighted.

\section{How to use it}

- Click on the Add sticky note icon in the Annotations section.

- Click at the point in the proof where the comment should be inserted.

- Type the comment into the yellow box that appears.

lallu allu suppiy silucks. hivst vi

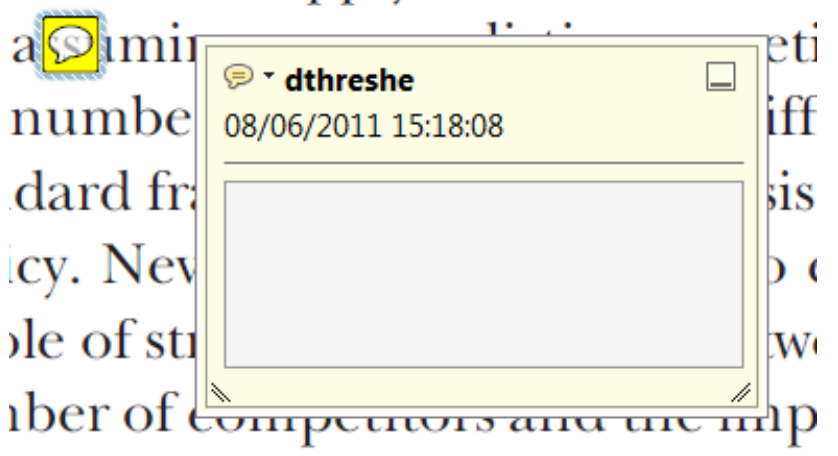

is that the structure of the secto 
5. Attach File Tool - for inserting large amounts of text or replacement figures.

Inserts an icon linking to the attached file in the appropriate pace in the text.

How to use it

- Click on the Attach File icon in the Annotations section.

- Click on the proof to where you'd like the attached file to be linked.

- Select the file to be attached from your computer or network.

- Select the colour and type of icon that will appear in the proof. Click OK.

E N D

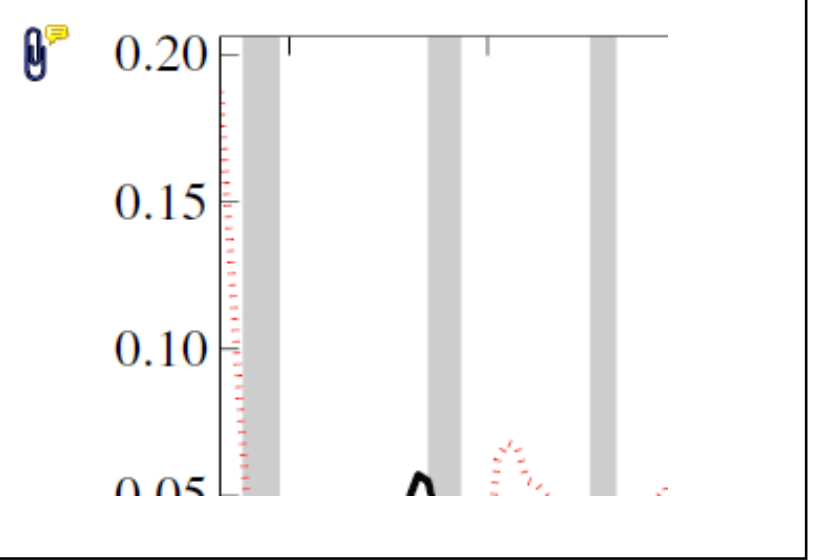

6. Add stamp Tool - for approving a proof if no corrections are required.

- Inserts a selected stamp onto an appropriate place in the proof

\section{How to use it}

- $\quad$ Click on the Add stamp icon in the Annotations section.

- $\quad$ Select the stamp you want to use. (The Approved stamp is usually available directly in the menu that appears).

- Click on the proof where you'd like the stamp to appear. (Where a proof is to be approved as it is, this would normally be on the first page).

of the Dusiness cycie, starting with the on perfect competition, constant ret

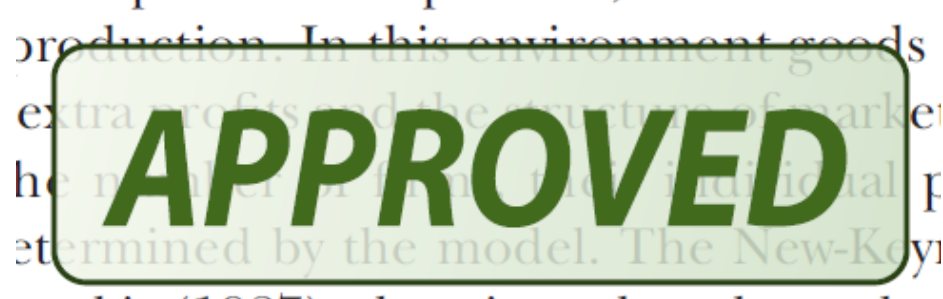

otaki (1987), has introduced produc general equilibrium models with nomin
- Drawing Markups

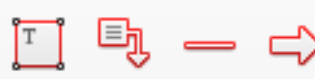

$0 \square \sqrt{6} D$

\section{How to use it}

- Click on one of the shapes in the Drawing Markups section.

- Click on the proof at the relevant point and draw the selected shape with the cursor.

- To add a comment to the drawn shape, move the cursor over the shape until an arrowhead appears.

- Double click on the shape and type any text in the red box that appears.
7. Drawing Markups Tools - for drawing shapes, lines and freeform annotations on proofs and commenting on these marks.

Allows shapes, lines and freeform annotations to be drawn on proofs and for comment to be made on these marks.

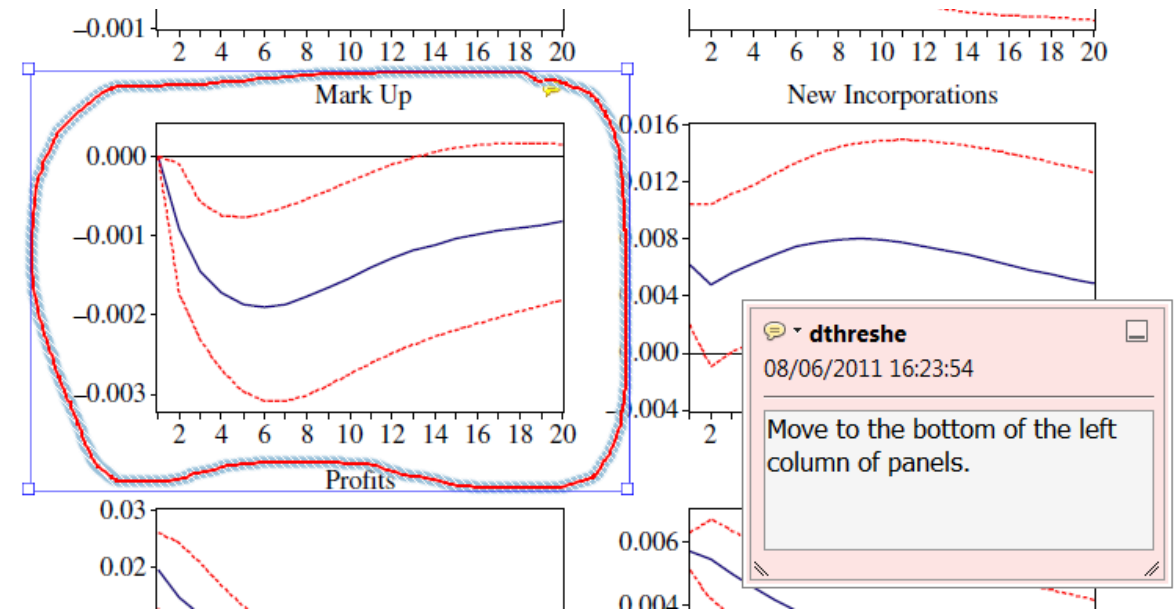

For further information on how to annotate proofs, click on the Help menu to reveal a list of further options:

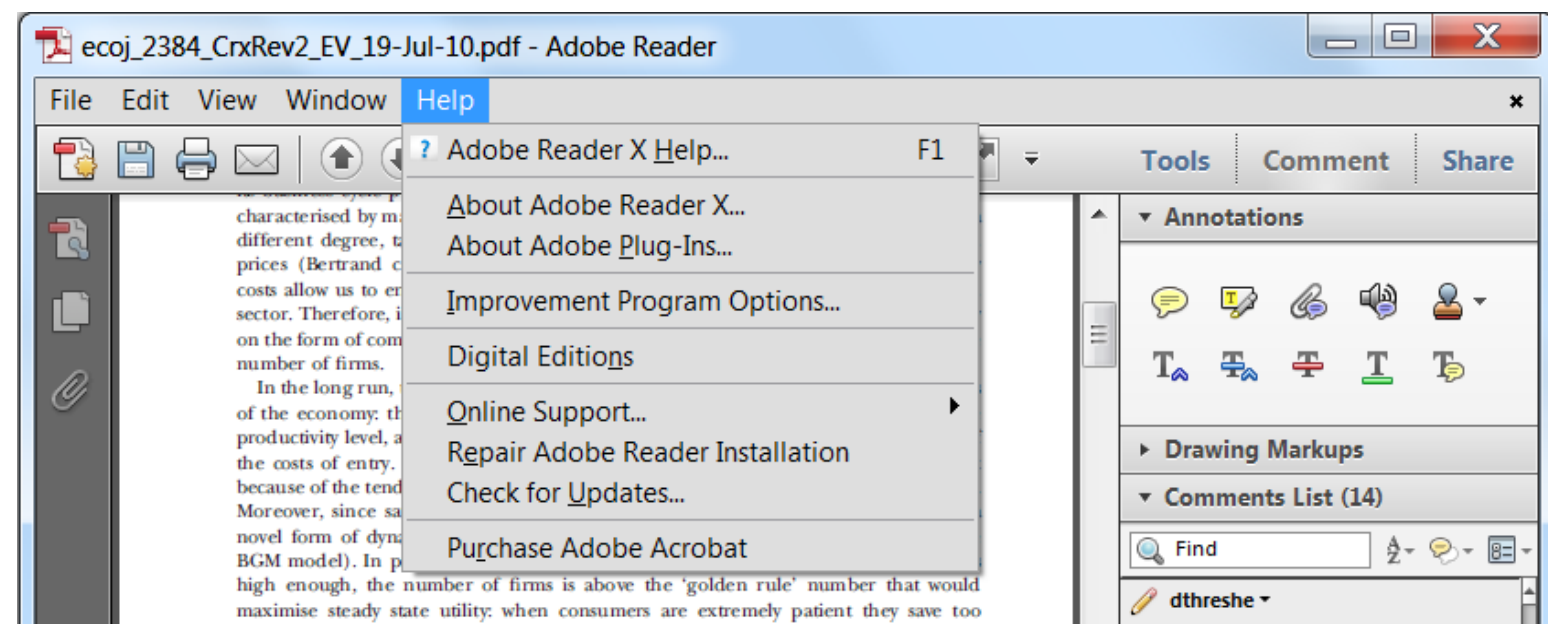

